\title{
THE USE OF DIGIPRENEUR AND SOCIOPRENEUR ON ENTREPRENEURSHIP INTEREST OF VOCATIONAL SECONDARY SCHOOL STUDENTS
}

\author{
Lucia Warisetyaningsih ${ }^{1}$, Erni Murniarti ${ }^{2} \bowtie$, Desideria Regina ${ }^{3}$ \\ SMK Santa Maria Bekasi Indonesia, Indonesia. \\ ${ }^{2}$ Universitas Kristen Indonesia, Indonesia. \\ Universitas Kristen Indonesia, Indonesia
}

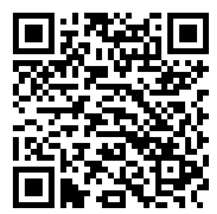

Received 1 September 2021

Accepted 14 September 2021

Published 30 September2021

CorrespondingAuthor

Erni Murniarti, erni.murniarti@uki.ac.id DOI

10.29121/granthaalayah.v9.i9.2021. 4232

Funding: This research received no specific grant from any funding agency in the public, commercial, or not-for-profit sectors.

Copyright: (C) 2021 The Author(s). This is an open access article distributed under the terms of the Creative Commons Attribution License, which permits unrestricted use, distribution, and reproduction in any medium, provided the original author and source are credited.

\section{ABSTRACT}

This analysis aims to determine how the influence of the use of digipreneur and sociopreneurship on the entrepreneurial interest of vocational students. Especially with the condition of economic digitization which has become an icon of the factory revolution 4.0 at this time, it is a "threat" for business operators who always insist on implementing and managing their business in conventional ways. Digipreneurs have had a tremendous impact on the current entrepreneurial development. This has resulted in the creation of new technology-based entrepreneurs in developing their business innovations. No less than among young people equivalent to vocational high school students. It is different with sociopreneur whose development is an effort to improve the welfare of the people in the surrounding environment so that they can solve social problems with a business approach. Perfect and planned and prolonged social entrepreneurship can be tried through learning activities that lead to the development of sociopreneurs from vocational high school students. As the younger generation, they are agents of change who can share socio-economic changes by providing the latest opportunities for the community.

Keywords: Digipreneur, Interest in Entrepreneurship, Sociopreneurship

\section{INTRODUCTION}

Vocational secondary education is one of the types of learning in Indonesia. Vocational High School is the embodiment of vocational education that has a special training pattern to prepare students to be ready to enter the business world/industrial world. Vocational secondary education has begun to be in demand in recent years because it has certain advantages and privileges compared to others. One of them is being able to open their own business with the knowledge and skills they have had since school. In this school, vocational students are directed to become entrepreneurs after graduation. An introduction to entrepreneurship is instilled since students enter VHS. It is hoped that the provision of entrepreneurship education will open up their knowledge of the world of entrepreneurship and can later be used as provisions for the future. Thus, the alumnus of the Vocational High School (VHS) will not only become a job seeker but can also become a competent and reliable job creator.

In this global era, business, technology, and information are always changing rapidly. Indonesia's creative industry currently allows the development of a digital-based business world. The road is wide open for digipreneurs in developing their business. All circles of society are competing to try their luck in 
entrepreneurship with this digital-based business. Do not miss also from the middle school students. Marketing opportunities will be more significant when information technology is included. Digipreneurs can help promote entrepreneurship and innovative culture in a country.

It is different with sociopreneurs who hope to be able to make social change on a broad scale, long-term, stable, and deep. Sociopreneur development is an effort to improve the welfare of the people in the surrounding environment. As someone who can let go of individual needs for many people and is not only concerned with personal gain. Adrian Liem said that one of the personalities that separate business entrepreneurs and social entrepreneurs are social attention and community understanding (altruism). This altruistic individual has 5 characters, namely high empathy, belief in balanced earth, social responsibility, internal locus of control, and low egocentrism Liem (2013).

Interestingly, this sociopreneur activity can run in the current digipreneur era and can finally increase the interest in entrepreneurship of VHS students who incidentally still have a great desire to get the maximum personal benefit compared to the common welfare. This is what makes the author want to analyze the use of digipreneur and sociopreneur on the entrepreneurial interest of vocational students.

\section{MATERIALS AND METHODS}

\section{Vocational High School}

The free market that is increasingly widespread today makes business opportunities wider open. The competition will be even tougher, especially with the development of e-commerce applications as a supporter of current digipreneurs. As an entrepreneur who must be able to survive in this era of globalization, knowledge, and skills are also needed. The advantage of a vocational high school has features that highlight it. The following are the privileges and advantages possessed by Vocational High Schools (VHS): (Wahyu, 2018)

1) Vocational skills are more mastered and taught

2) Prioritizing practical lessons

Vocational High Schools have additional skills lessons under their area of expertise. The theory lessons will be delivered first before students get practical theory to know the stages first before plunging into practice.

3) Implement industrial work practices (prakerin)

This internship must be done by VHS students for 6 months and when they sit in class XI even semester. This is important so that students understand and know how to become a worker or employee according to the competency skills they learn at school. It is their prakerin certificate that is favored to be ready to work after graduating from VHS.

4) VHS graduates are ready to work

5) Easier opportunities to open a business

Many vocational students today prefer to open their own business rather than work for someone else. Having a stock of expertise while in vocational high school, can make them have brilliant ideas to utilize the skills they have, especially those that are explored and guided continuously during school. 


\section{Digipreneur}

The development of digital technology and nowadays has given birth to new business opportunities, namely digipreneur. For example, from the field of photography, we can easily find photographic works on the Instagram page. Confused with the recipe we want to make, we can easily find it on the Instagram page, Twitter, Facebook, and so on. It is this digital life that begins to focus on the revival of the digitalization era, everything will be digital. A job applicant doesn't even need to come directly to the job provider's office. All test steps are done online. The use of print media has also decreased, many turning to digital form. Digital in the KBBI itself is defined as the process of giving or using a digital system.

Digitization in the business world or business has also penetrated the digital market and has the name digital entrepreneurship, popularly known as digipreneur. This activity is attached to the souls who have brilliant ideas, are creative, can move dynamically, effectively, and efficiently. These souls are owned by young people. Examples of young digipreneurs we know: Manggala (2017)

1) Nurfadli (comic tahilalats)

Starting from his social media which he uses to spread his comics.

2) Danny (slapstick)

This joke is also packaged in the form of comics, game applications, and others. This joke can contribute to the provision of employment, so far 60 employees are working in it.

3) Marcella (90s generation)

Starting from the final project as a student of DKV Capital to be a digipreneur is not easy, especially for business actors. How to develop digipreneur starts from the steps of newcomers who have initial inspiration to get results from their hard work activities.

The following are the three main capitals of becoming a digipreneur as stated by Muhammad Awaludin in his book entitled "Digital Entrepreneurship": Fauziyah (2018)

1) Mindset

A positive mindset must always be instilled, ready and brave to face obstacles or challenges due to dynamic changes in the digital world.

2) Learn to understand conditions

An entrepreneur must practice mastering environmental situations, energetic market changes, competitor agility, to the impact of technology in business so that the mindset that has been instilled can run efficiently.

3) Networking

No effort can run alone, therefore entrepreneurs need networking or networking as a base for insights, ideas, and data for business development. So that this networking can run easily, entrepreneurs must act open and open themselves to make friends with many parties.

By applying digital technology, it will automatically allow small businesses to reach large target markets. By creating a website, small businesses have the opportunity to sell their services to all areas. Musnaini (2020) 


\section{Sociopreneur}

According to Nicholls Prayogo (2017), sociopreneurship originates from the words social and entrepreneurship. Social has a social purpose, on the other hand, entrepreneurs have entrepreneurial intentions. The simple definition of a social entrepreneur is someone who knows and wants to understand social issues and uses his entrepreneurial skills to organize, create, and manage a business to carry out and bring about social change, especially in the aspects of safety, learning, and health. A social entrepreneur will serve the lower middle class to eliminate gaps in safety, learning, health, demographics, and job opportunities Prayogo (2017). The sociopreneur element emphasizes two key elements, namely innovation (creative process to produce something new), creating social values.

\section{RESULTS AND DISCUSSIONS}

Various program activities are carried out by vocational high schools to produce young entrepreneurs who can open new jobs in today's digital business world. Santa Maria Vocational High School (VHS) is one of the vocational schools that aims to form young entrepreneurs who can bring change in the surrounding community by referring to sociopreneurs such as their core value, namely being a smart, independent, loving sociopreneur school. Entrepreneurial activities in learning that are mostly carried out in skill competency activities aim to increase their interest in entrepreneurship later after graduating from VHS. With the current Indonesian creative industry, it is possible to develop a digital-based business world. The road is wide open for digipreneurs in developing their business. This is what makes skill competency teachers at Santa Maria Vocational School encourage students to be able to use this digital world to market the products/services they produce in their skill competency learning activities.

In a simple observation survey that I conducted to 30 student council members at Santa Maria Vocational School with several question instruments related to digipreneurs, sociopreneurs and their entrepreneurial interests, it can be concluded that digipreneurs and sociopreneurs currently affect the entrepreneurial interest of Santa Maria Vocational School students.

While studying entrepreneurship, as many as $82.4 \%$ are happy and interested in this lesson because their entrepreneurial skills can improve, become more motivated, and can see market-oriented opportunities.

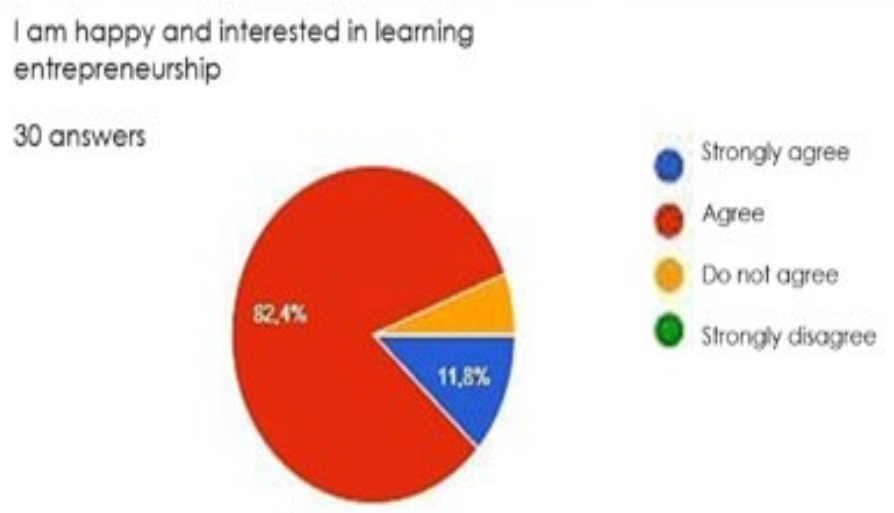

Figure 1 
My entrepreneurial skills improve after studying

30 answers
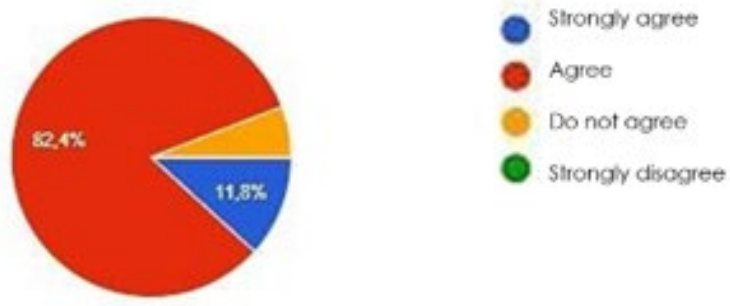

Figure 2

I hove the motivation to excel when studying entrepreneurship

30 answers

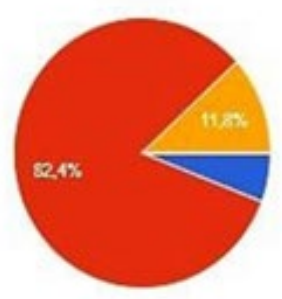

Strongy agree

(2) Agree

Do not agree

Strongy disagroo

\section{Figure 3}

Entrepreneurship means opening up business opportunities for me and others 30 answers
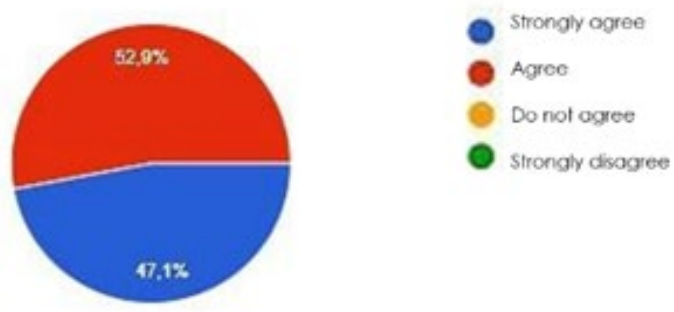

Figure 4

Production unit activities (practice) allow me to do market-oriented work 30 answers
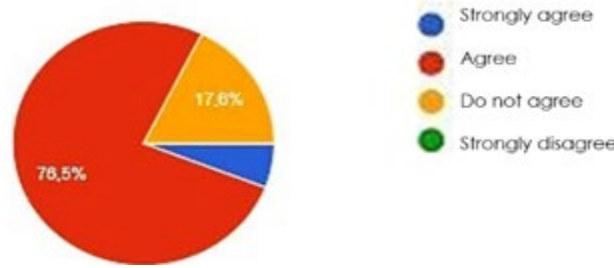

Figure 5 
From the practical activities of the production unit according to their expertise competency as much as $68.8 \%$ is a means and place for business training for them. This is what encourages them to be able to create their own work with the abilities they have and to develop it they want to take part in motivational exercises as a preparation for entrepreneurship.

Production unit activities (practices) are facilities and places for business training

30 answers

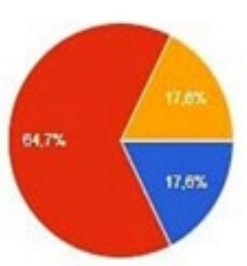

\section{Figure 6}

I will create my work with the abilities that I have

30 answers
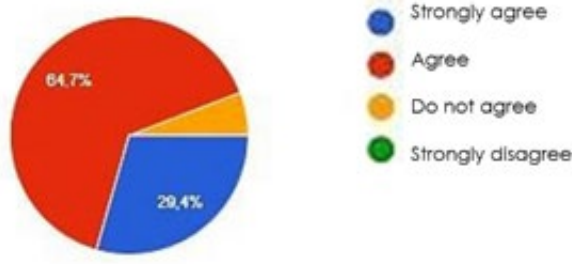

\section{Figure 7}

I want to take part in motivational training as a provision for entrepreneurship

30 answers

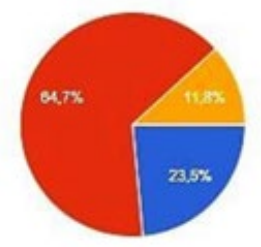

Strongly agree

C Agree

- Do not agree

Strongly disagree

\section{Figure 8}

Production unit activities (practices) encourage me to develop an entrepreneurial spirit

30 answers

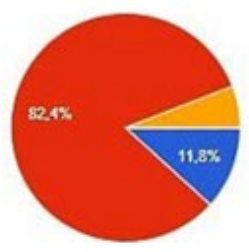

Strongly agree

Agree

Do not agree

strongly disagree 
Figure 9

Currently, $56 \%$ of them already own or start a business, and the e-commerce platform or application they usually use as digipreneur support is Shopee in the first position, then Tokopedia and Lazada and have the desire to create their e-commerce website. Connected with the sociopreneur, the student said that as an entrepreneur they would not only be concerned with maximizing profit but would also pay attention to the environment around those in need.

I already own or start a business now

30 answers

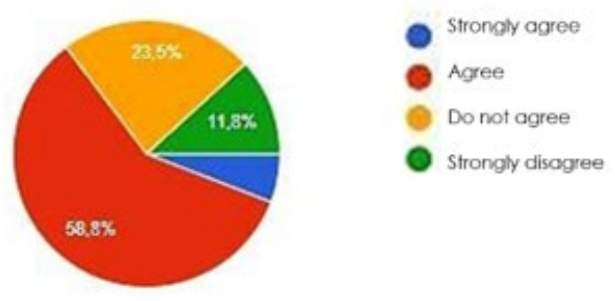

Figure 10

An e-commerce platform or application that I will or have used as a support to become a digipreneur

30 answers

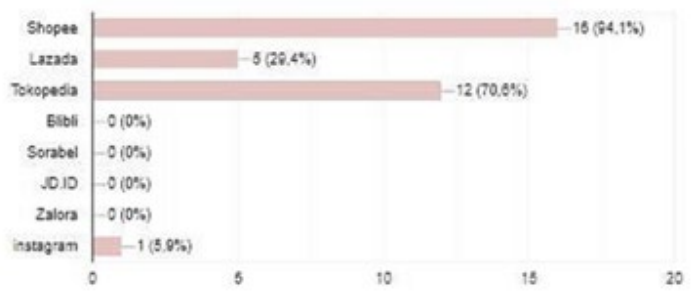

\section{Figure 11}

I want to have an E-Commerce website to support my digipreneur

30 answers

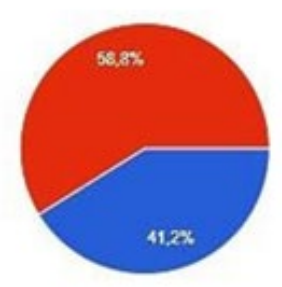

Strongly agree

Agree

Do not agree

Strongly disogreo

Figure 12 

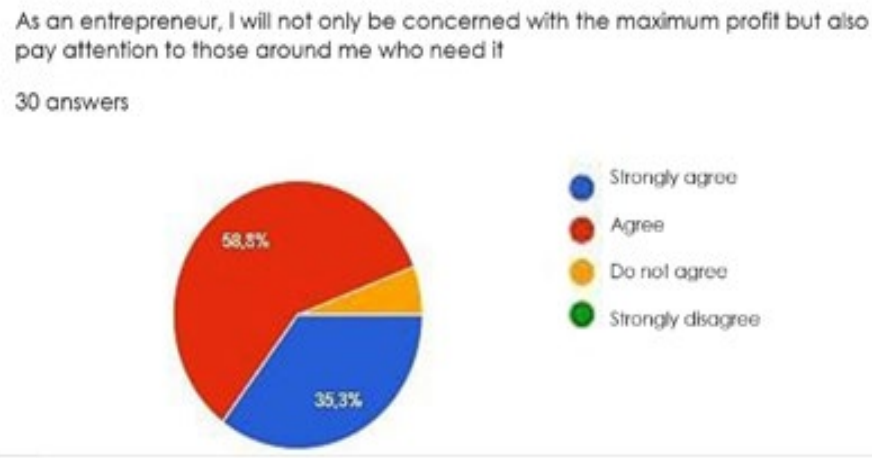

Slrongly agroe

\section{CONCLUSIONS AND RECOMMENDATIONS}

Based on the results of a simple observation survey that has been described by the author above, it can be concluded that digipreneur and sociopreneur have an influence on the entrepreneurial interest of vocational students. This can be seen during the study of entrepreneurship, students are happy and interested because their entrepreneurial skills can improve, are more motivated, and are able to see market-oriented opportunities. Production unit activities can be a means and place for business training for those who are encouraged to create their own jobs. The ecommerce platforms or applications that they usually use to support digipreneurs in developing the businesses they have started are Shopee, Tokopedia, and Lazada. As an entrepreneur, they also want not only to be concerned with maximizing profits but also to pay attention to the environment around those in need.

Based on these conclusions, it is hoped that students' skill competency learning can continue to be improved and sharpened again and continue to instill sociopreneurs in every learning process and be able to collaborate with current digipreneurs to develop their marketing practice skills so that the interest in entrepreneurship of VHS students continues to increase.

\section{REFERENCES}

Alim, A. (2018). Pengaruh Peran Sociopreneurship Terhadap Keberhasilan Usaha (Studi Pengusaha UMKM Pada Debitur di PT. Esta Dana Ventura). Jurnal Online Nasional, 1-13. from http://download.garuda.ristekdikti.go.id/article.php?article=1271920\&val =16170\&title=PENGARUH\%20PERAN\%20SOCIOPRENEURSHIP\%20TERH ADAP\%20KEBERHASILAN\%20USAHA\%20Studi\%20Pengusaha\%20UMK M\%20Pada\%20Debitur\%20di\%20PT\%20Esta\%20Dana\%20Ventura

Misrah. (2019). Analisis Minat Berwirausaha Mahasiswa Angkatan 2015-2018 Pendidikan Ekonomi Fakultas Ekonomi Universitas Negeri Makasar. eprints.unm.ac.id.

Syabilla, N. (2015), Oktober 23). Makalah Sociopreneur. Retrieved Mei 09, 2021, from www.slideshare.net: Retrieved from https://www.slideshare.net/NadyaSyabillaA/makalah-sociopreneur 


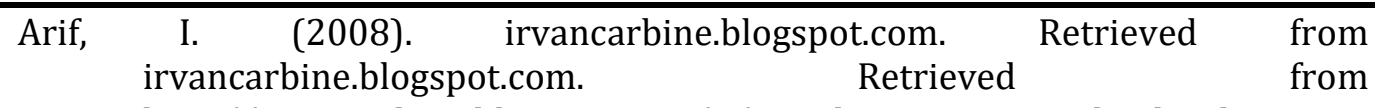
http://irvancarbine.blogspot.com/p/social-entrepreneurship.html

JabarEkspres.com. (2018), Februari 03). Retrieved from https://jabarekspres.com: Retrieved from https://jabarekspres.com/berita/2018/02/03/yuk-kenalidigipreneur/3/

Fauziyah, A (2018) “3 modal utama jadi digipreneur,” Retrieved from digination.id: Retrieved from https://www.digination.id/read/01961/3-modal-utamajadi-digipreneur.

Liem, A (2013) "Penanaman Nilai dan Moral pada Anak sebagai Modal Sociopreneur Melalui Dongeng," J. Entrep. dan Entrep., vol. 2, no. 1, pp. 13-22. Retrieved from https://doi.org/10.37715/jee.v2i1,2.769

Manggala, P (2017) “Kompasiana Beyond Blogging. ?page=all. Retrieved Mei 9, 2021. $\quad$ Retrieved from https://www.kompasiana.com/prischamanggala/5831caa7af7e610913fc9 34f/kisah-membangun-usaha-digipreneur-sejak-muda

Musnaini, Wijoyo, H., Indrawan, I., Digipreneurship (Kewirausahaan Digital). (2020) Banyumas: Pena Persada. Retrieved from https://www.researchgate.net/profile/Hadion-

Wijoyo/publication/343007851_DIGIPRENEURSHIP_KEWIRAUSAHAAN_D IGITAL/links/5f117a13a6fdcc3ed70e5279/DIGIPRENEURSHIPKEWIRAUSAHAAN-DIGITAL.pdf

Prayogo,C (2017) Studi Deskriptif Social Entrepreneur Pada Pemilik Agfa di Sidoarjo, Jawa Timur, Indonesia. Agora. Retrieved from http://publication.petra.ac.id/index.php/manajemen-

bisnis/article/view/5296 